\title{
INHIBITION OF HERPES VIRUS ADSORPTION BY TWO FRACTIONS OBTAINED FROM COMMERCIAL PROTAMINE SULFATE.
}

\author{
SHIGERU YAMAMOTO, HIDEFUMI KABUTA \\ AND YOH NAKAGAWA \\ Department of Microbiology, Kurume. University School \\ of Medicine, Kurume, Japan
}

(Received for publication December 8, 1970)

\begin{abstract}
The commercial protamine sulfate could be separated into two fractions by Sephadex G-50 column which inhibited plaque formation by herpes simplex virus when cell monolayers were treated with them before adding the virus. One of them (Fr. I) contains high molecular weight proteins and the other (Fr. II) contains only protamine molecules. The former is more effective than the latter. The inhibitory effect disappears after incubation of the fractions with a large amount of cells. Both fractions do not directly reduce virus infectivity. Furthermore, they do not inhibit virus replication after virus adsorption. The virus particles remaining unadsorbed to cells pretreated with the fractions could be detected only when virus diluted in Earle's saline containing skim milk and lactalbumin hydrolysate was used for inoculation. These findings gave. a clear evidence that protamine (Fr. II) and also high molecular weight proteins in Fr. I adsorb to cell surface or receptor and in consequence inhibit virus attachment to the cell surface resulting in the reduction of plaque formation.
\end{abstract}

The basic proteins and the synthetic basic polymers affect the interaction of virus or viral RNA with cells although they are different in effect among a variety of viruses. In some cases they interfere with the virus-cell interaction $^{34) 13)}$, but in others enhance it ${ }^{1}$ 9) 11) 12) 14). Recently, the contrasting effects were found even between two variants of encephalomyocarditis virus ${ }^{5)}$.

It was revealed in the previous report that the plaque formation by herpes simplex virus was also reduced if the cell monolayers were exposed to protamine sulfate before inoculation with the virus ${ }^{17)}$. It has been found that the commercial protamine sulfate can be separated into two protein fractions by gel filtration. This paper deals with the comparison of effects of the two fractions on virus-cell interaction, and the evidence obtained here demonstrates that both fractions bind to the cell surface and inhibit the adsorption of virus particles to cell resulting in the reduction of plaque formation. 


\section{MATERIALS AND METHODS}

Cells. G-7 cells, a clone isolated from GMK cells (established African grivet monkey kidney cells), were grown in 2-oz bottles with approximately one million cells using a mixture consisting of 7 parts of Hank's saline containing $0.5 \%$ lactalbumin hydrolysate and 3 parts of Eagle's medium, supplemented with $10 \%$ heated $\left(56{ }^{\circ} \mathrm{C}, 30\right.$ minutes $)$ bovine serum.

Virus. The M strain of herpes simplex virus had been transfered ten times in GMK cell cultures following its isolation from a case with Herpes labialis. Characteristics of this strain have been described previously ${ }^{8)}{ }^{16}$.

Solution. Phosphate-buffered saline, $\mathrm{pH} 7.2$ (PBS), and that deprived of $\mathrm{MgCl}_{2}$ and $\mathrm{CaCl}_{2}$ (PBS (-)) were prepared according to Dulbecco and Vog $\mathrm{t}^{6)}$. Earle's saline supplemented with $0.5 \%$ skim milk and $0.125 \%$ lactalbumin hydrolysate (MLE) was used in some experiments.

Protamine.

Protamine sulfate (salmine) was obtained from Nutritional Biochemicals Corp.

Fractionation of protamine sulfate by Sephadex. Protamine sulfate was dissolved in PBS( $\rightarrow$ ) at a concentration of $50 \mathrm{mg} / \mathrm{ml}$ and yielded a turbid solution which was centrifuged at 10,000 r.p.m for ten minutes at 25 to $28^{\circ} \mathrm{C}$, and filtered through a $0.22 \mu$ Millipore filter. Two to four $\mathrm{ml}$ of the filtrate were applied on Sephadex G-50 column, $2 \times$ $20 \mathrm{~cm}$, and eluted with $\operatorname{PBS}(-)$.

Protein estimation. The protein content in each fraction was measured by the method of Lowry et al. ${ }^{10}$ ) using bovine albumin as a standerd.

Treatment of cell monolayers with the fractions. The two-day old monolayer cultures were washed twice with five ml PBS. The washed monolayers were exposed to five $\mathrm{ml}$ of the fraction appropriately diluted with PBS for one hour at $37^{\circ} \mathrm{C}$. Control cultrures were exposed to PBS under the same conditions. The cultures were then washed twice with PBS and followed by standing in five $\mathrm{ml}$ PBS for 30 minutes at room temperature to remove completely the substances in the fraction from culture bottles. After the fluid was drained off, the monolayers were inoculated with two tenth $\mathrm{ml}$ of virus suspension in PBS containing 50 to 100 PFU (plaque forming units). Four to five bottle cultures were used for one titration. The virus was allowed to adsorb for two hours at $37^{\circ} \mathrm{C}$ and overlaid according to the method as described previously ${ }^{16)}$.

\section{RESULTS}

Fractionation of protamine sulfate by Sephadex G-50 and the effect on plaque formation. Two $\mathrm{ml}$ of prota-

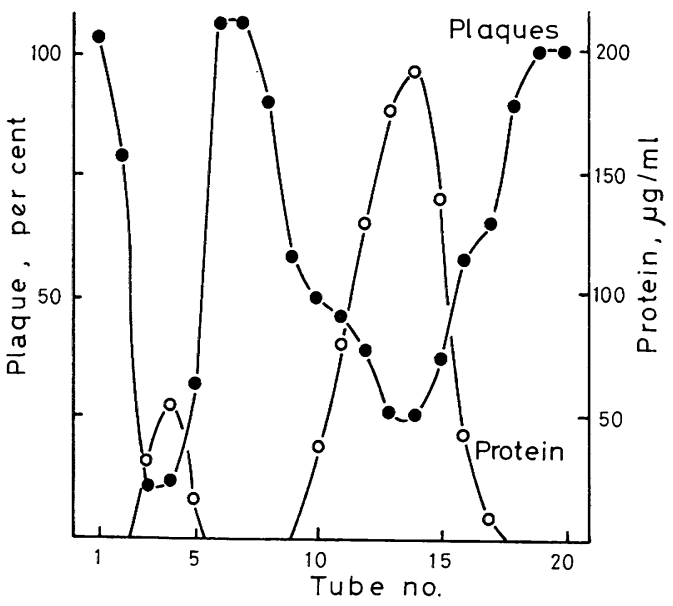

Fig. 1 Fractionation of protamine sulfate by Sephadex G-50.

Two $\mathrm{ml}$ of protamine solution were applied on the column, $2 \times 20 \mathrm{~cm}$, and eluted with PBS (-). The first $15 \mathrm{ml}$ were discarded. Every fraction $(2 \mathrm{ml})$ was diluted 25 times with PBS and used for treatment of cell monolayers. Aliquots from diluted fractions were assayed for protein content. 
mine sulfate solution were applied to Sephadex G-50 column. Fractions of two $\mathrm{ml}$ were collected and diluted with $48 \mathrm{ml}$ PBS and the effect on plaque formation was tested. At the same time, aliquots from the diluted fractions were assayed for protein content. As illustrated in Fig. 1, two peaks of protein were obtained and the first one was more effective on the reduction in the number of plaques formed by $M$ strain than the second peak, although it contained smaller amount of protein than the other. In addition, no alteration of plaque characteristics was observed with these peaks. The first peak appeared also in excluded fraction when it was rechromatographed through the column of Sephadex G-100.

The tubes 3 to 5 and 12 to 14 were pooled and referred to as Fr. I and Fr.
II, respectively, for the following experiments. As the eluants appearing after the tube 15 were contaminated with excess of $\mathrm{So}_{4}^{--}$ions derived from the original solution of protamine sulfate, they were not used for experiments.

Effect of the exposure time on plaque reduction. The washed monolayers were exposed to 45 and $130 \mu \mathrm{g} / \mathrm{ml}$ of Fr. I and Fr. II, respectively, and PBS at $37^{\circ} \mathrm{C}$. At the given time, the monolayers were washed and tested on plaque formation. Fig. 2 indicated that maximum reduction was achieved at 30 minutes in both cases. Incubation over 90 minutes reduced the number of plaques in the control monolayers which were exposed to PBS. Therefore, the incubation for 60 minutes seems to be adequate for estimating the reduction of plaques by Fr. I or Fr. II.

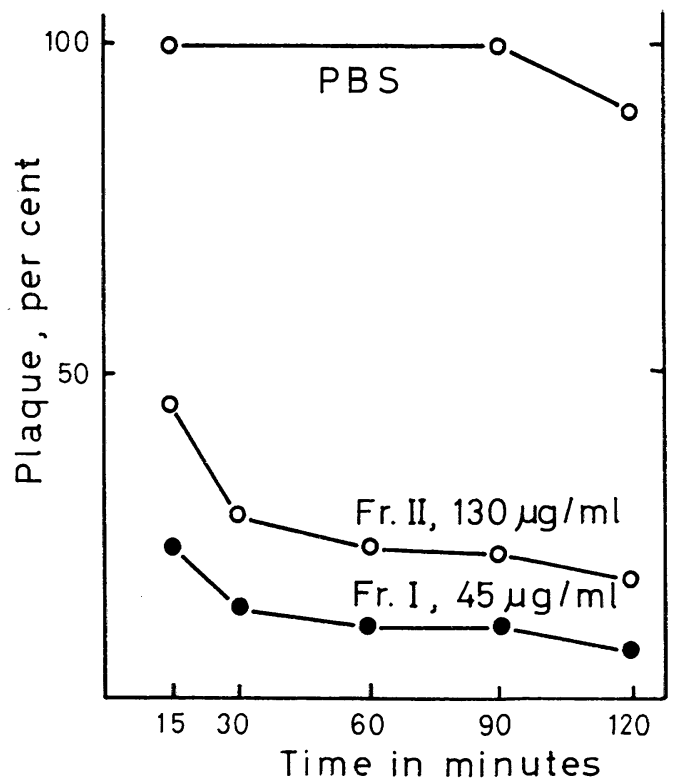

Fig. 2 Effect of the exposure time on plaquing efficiency.

Cell monolayers were incubated with Fr. I or Fr. II for the indicated period before addition of virus.

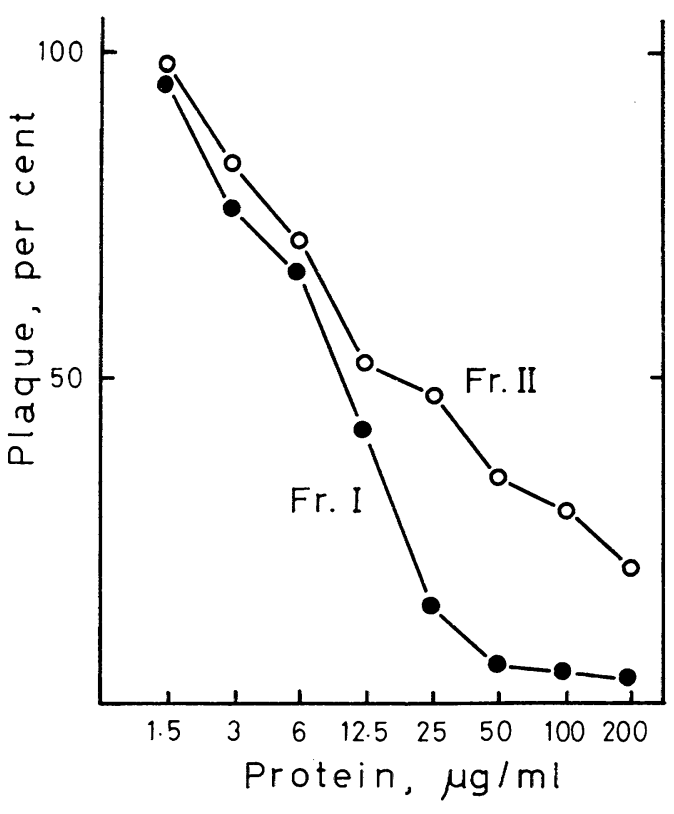

Fig. 3 Effect of pretreatment of cell monolayers with different concentrations of Fr. I and Fr. II on plaquing efficiency. 
Reduction of plaques by various concentrations of Fr. I and Fr. II.

The relationship between the concentration of Fr. I or Fr. II with which the cell monolayers were treated and the number of plaques formed were illustrated in Fig. 3. Below the concentration of $6 \mu \mathrm{g} / \mathrm{mI}$, the reduction of the number of plaques was not so different between Fr. I and Fr. II, whereas, over this concentration, Fr. I markedly reduced the number of plaques formed in comparison with Fr. II. The effetiveness of Fr. I was not enhanced by increasing the concentration at higher than $50 \mu \mathrm{g} / \mathrm{ml}$. Fr. I and Fr. II were not toxic to cells at the concentration lower than $200 \mu \mathrm{g} / \mathrm{ml}$.

Effect of Fr. I and Fr. II on virus infectivity. The virus suspension which contained approximately $5 \times 10^{7} \mathrm{PFU} / \mathrm{ml}$ was mixed with an equal volume of $\mathrm{PBS}$, $2 \mathrm{mg} / \mathrm{ml}$ of Fr. I and Fr. II. After incubation for one hour at $37^{\circ} \mathrm{C}$ with shaking, the mixture was diluted 100,000 times and inoculated on to the cell monolayers for plaque assay. The trace amount of Fr. I and Fr. II remaining. in diluted mixtures should be too low in the concentration to affect the plaque formation. The PFUs of the diluted mixtures treated with Fr. I , Fr. II and PBS were 198.5, 176.5 and 191.5 per $\mathrm{ml}$, respectively. The values are not significantly different indicating that the virus particle is not inactivated by either Fr. I or Fr. II.

Effect of Fr. I and Fr. II on virus replication. Monolayer cultures were washed twice with PBS and inoculated with $0.2 \mathrm{ml}$ virus suspension. The inoculum contained 3 PFU per cell, which were allowed to adsorb for two hours at $37^{\circ} \mathrm{C}$. The cell monolayers were then washed five times with PBS and incubated at $37^{\circ} \mathrm{C}$ in four $\mathrm{ml}$ of Eagle's medium or of that containing

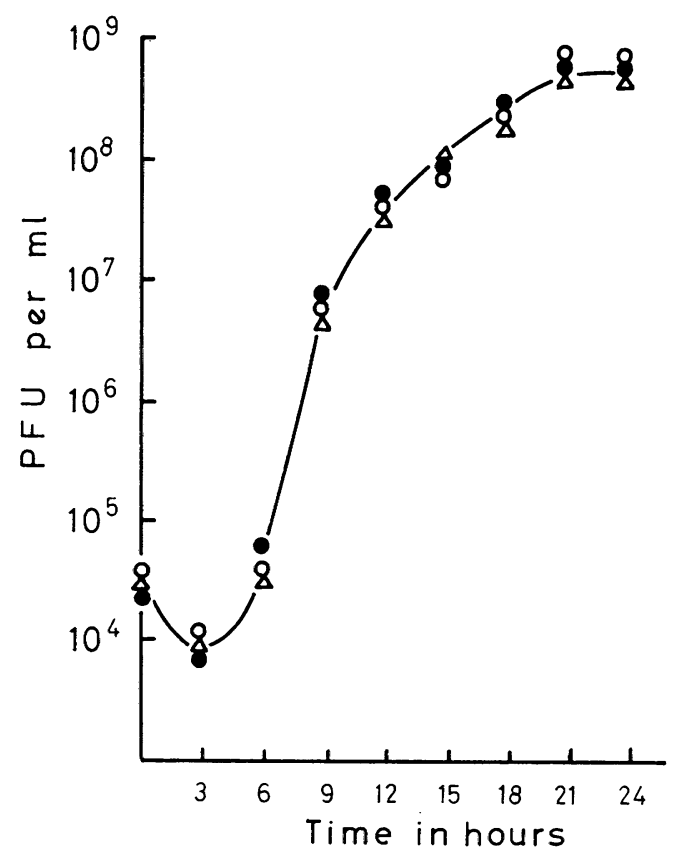

Fig. 4 Virus replication in the presence of Fr. I and Fr. II .

Cells were inoculated with virus at a multiplicity of 3 PFU per cell. After adsorption for two hours, the cultures were washed five times and incubated at $37^{\circ} \mathrm{C}$ in four $\mathrm{ml}$ medium. At the time intervals indicated, the virus was harvested and assayed. The media were Eagle's medium $(\Delta)$, Eagle's medium containing $25 \mu \mathrm{g} / \mathrm{ml}$ of $\mathrm{Fr}$. I (•) and Eagle's medium containing $25 \mu \mathrm{g} / \mathrm{ml}$ of $\mathrm{Fr}$. II (0).

$25 \mu \mathrm{g} / \mathrm{ml}$ of Fr. I or Fr. II. At each time interval indicated in Fig: 4, the cultures were frozen and thawed and followed by sonication for two minutes at $20 \mathrm{kc} / \mathrm{sec}$. Fig. 4 shows that both fractions do not affect or slightly enhance virus replication after virus adsorption. Maximum yield of virus was observed 21 hours after adsorption in every case, and at this time more virus was found in cultures with Fr. I and Fr. II than in control (1200, 1300 and $850 \mathrm{PFU}$ per cell, respectively). 
Adsorption of Fr. I and Fr. II with cells. An experiment was designed to see if there was a possibility that the substances in Fr. I and Fr. II may bind to cell surface and result in the inhibition of virus attachment to the cell. The cells were dispersed by trypsin and washed twice with a large amount of PBS. The cells were suspended to give a suspension containing $5 \times 10^{7}$ cells in $25 \mathrm{ml}$ of PBS, Fr. I and Fr. II (15 $\mu \mathrm{g} / \mathrm{ml})$, and incubated at $37^{\circ} \mathrm{C}$ for one hour with intermittent shaking. After incubation, the suspension was centrifuged to remove cells and the supernatant fluid was added to cell monolayers in order to see the effect on plaque formation.

Further adsorption, when necessary, was carried out by the same procedure as above. The results are shown in Table 1. It is clear that the plaque reducing effect of Fr. I was completely diminished by preincubation with cells, while five cycles of adsorption were required to reverse the inhibitory effect of Fr. II. The result may be attributed to the difference in molecular size of substances contained in Fr. II. As the behavior in Sephadex column showed that the substances in Fr. II was lower molecular size than those in Fr. I, the concentration in Fr. II may be higher on a molar basis. This may accordingly result in the requirement of larger amount of cells for adsorbing the substances in Fr. II.

TABLE 1

Effect of adsorption of Fr. I and Fr. II with cells on plaquing efficiency

\begin{tabular}{l|c|c|c|c}
\hline & \multicolumn{2}{|c|}{ Before adsorption } & \multicolumn{2}{|c}{ After adsorption } \\
\cline { 2 - 5 } & $\begin{array}{c}\text { av. no. of } \\
\text { plaques }\end{array}$ & $\begin{array}{c}\text { plaquing } \\
\text { efficiency }\end{array}$ & $\begin{array}{c}\text { av. no. of } \\
\text { plaques }\end{array}$ & $\begin{array}{c}\text { plaquing } \\
\text { efficiency }\end{array}$ \\
\hline Expt. 1 & & & adsorbed $1 \times$ with cells \\
Fr. I, $15 \mu \mathrm{g} / \mathrm{ml}$ & 39.3 & 33 & 118.4 & 107 \\
Fr. II , $15 \mu \mathrm{g} / \mathrm{ml}$ & 51.4 & 44 & 55.0 & 50 \\
PBS & 118.2 & 100 & 110.0 & 100 \\
\hline Expt. 2 & & & adsorbed $5 \times$ with cells \\
Fr. II, $15 \mu \mathrm{g} / \mathrm{ml}$ & 51.3 & 55 & 77.0 & 86 \\
PBS & 93.0 & 100 & 89.3 & 100 \\
\hline
\end{tabular}

Adsorption was carried out by incubating the suspension of $5 \times 10^{7}$ cells in $25 \mathrm{ml}$ of Fr. I, Fr. II and PBS at $37^{\circ} \mathrm{C}$ for one hour.

Fate of unadsorbed virus. An attempt was made to study the fate of the virus particles. The inoculum which was adsorbed for two hours on cell monolayers pretreated with PBS, Fr. I or Fr. II $(25 \mu \mathrm{g} / \mathrm{ml})$ was removed and transferred to fresh cultures for estimation of unadsorbed virus. The virus for inoculation was diluted in PBS in one experiment, and in MLE in the other one. As shown in Table 2, when the virus in PBS was used, the amount of virus remaining in the inoculum applied to monolayers pretreated with Fr. I was significantly less than the control and that in the case of Fr. II was roughly comparable to it.

When the virus diluted in MLE was inoculated on to the cells pretreated with Fr. I and Fr. II, the plaquing 
TABLE 2

Inhibitory effect of pretreatment of cell monolayers on virus adsorption

\begin{tabular}{|c|c|c|c|c|c|c|}
\hline \multirow{2}{*}{$\begin{array}{c}\text { Pretreatment of } \\
\text { cultures with }\end{array}$} & \multirow{2}{*}{$\begin{array}{l}\text { Inoculation } \\
\text { with } \\
\text { virus in }\end{array}$} & \multicolumn{2}{|c|}{ Adsorbed virus } & \multicolumn{2}{|c|}{ Unadsorbed virus } & \multirow[b]{2}{*}{$\underset{\%}{\text { Recovery }}$} \\
\hline & & total PFU & $\begin{array}{l}\text { plaquing } \\
\text { efficiency }\end{array}$ & total PFU & $\begin{array}{l}\% \text { of } \\
\text { control }\end{array}$ & \\
\hline \multirow{4}{*}{$\begin{array}{l}\text { Expt. } 1 \\
\text { Fr. I, } 25 \mu \mathrm{g} / \mathrm{ml} \\
\text { Fr. II, } 25 \mu \mathrm{g} / \mathrm{ml} \\
\text { PBS }\end{array}$} & & & & & & \\
\hline & PBS & 59 & 14 & 61 & 80 & 24 \\
\hline & " & 209 & 50 & 84 & 111 & 60 \\
\hline & " & 415 & 100 & 76 & 100 & 100 \\
\hline \multirow{4}{*}{$\begin{array}{l}\text { Expt. } \\
\text { Fr. I, } 25 \mu \mathrm{g} / \mathrm{ml} \\
\text { Fr. II } 25 \mu \mathrm{g} / \mathrm{ml} \\
\text { PBS }\end{array}$} & & & & & & \\
\hline & MLE & 189 & 26 & 201 & 216 & 48 \\
\hline & " & 615 & 86 & 168 & 181 & 97 \\
\hline & " & 714 & 100 & 93 & 100 & 100 \\
\hline
\end{tabular}

After adsorption of virus to treated and untreated cell monolayers, the inoculum was removed and transferred to fresh cultures to estimate unadsorbed virus.

For estimation of adsorbed virus, the cultures were overlaid immediately after removal of the inoculum.

efficiencies were 26 and $86 \%$, respectively (Table 2, Expt. 2). These values are higher than those obtained in the experiment which carried out with the virus diluted in PBS (Table 2, Expt. 1). The reason is not clear but it seems that MLE can partially reduce the inhibitory effect probably by masking the substances contained in the fractions which previously adsorbed to the cell surface or by releasing them from the cell surface by competition with their binding site. In fact, MLE reacts with Fr. I and Fr. II and the precipitate is produced. Repeated experiments on Fr. II $(25 \mu \mathrm{g} / \mathrm{mI})$ using the virus diluted in MLE showed the plaquing efficiencies to be 75 to $88 \%$. Therefore, $86 \%$ plaquing efficiency (i.e, $14 \%$ reduction) seems to be significant although the difference from control is small.

Furthermore, more numbers of PFU were detected in the inocula which were applied to monolayers pretreated with Fr. I and Fr. II in comparison with the control. These results clearly demonstrate that substances in Fr. I and Fr. II inhibit adsorption of virus particles to cell surface resulting in the reduction of plaques. On the other hand, the discrepancy of the results with the unadsorbed virus obtained between experiments which were carried out with the virus in PBS and with that in MLE seems worthy of consideration. One possibility is that the virus particles remaining unadsorbed in the inoculum may be inactivated more rapidly in PBS than in MLE under the condition of the temperature of $37^{\circ} \mathrm{C}$ during adsorption period.

There exists another possibility that some component might be released from pretreated cells which would inactivate unadsorbed virus particles in PBS but not those in MLE. To test this possibility, the following experiments were undertaken. Two-tenth ml PBS were added to cell cultures pretreated with Fr. I, Fr. II and PBS. After incubation for two hours at $37^{\circ} \mathrm{C}$, the 'conditioned' fluid was collected and diluted two-fold stepwise with PBS after centrifugation. In one experiment, $0.3 \mathrm{ml}$ 
dilutions of the conditioned fluid were mixed with $0.3 \mathrm{ml}$ PBS and incubated at $37^{\circ} \mathrm{C}$ for 30 minutes and then $0.6 \mathrm{ml}$ of virus suspension appropyriatel diluted in PBS were added. After further incubation for 30 minutes at 37 or $25^{\circ} \mathrm{C}$, infectivities were determined. The other experiment was carried out by the same procedures except that $0.3 \mathrm{ml}$ dilutions of the conditioned fluid were mixed with $0.3 \mathrm{ml} \mathrm{MLE}$ instead of PBS. As shown in Table 3 , the conditioned

TABLE 3

Effect of "conditioned" fluid from pretreated cell monolayers on virus infectivity

\begin{tabular}{|c|c|c|c|c|c|c|c|}
\hline & \multirow{4}{*}{$\begin{array}{l}\text { Final dilution } \\
\text { of } \\
\text { conditioned } \\
\text { fluid }\end{array}$} & \multicolumn{6}{|c|}{ Conditioned fluid from cells pretreated with } \\
\hline & & \multicolumn{2}{|c|}{ Fr. I } & \multicolumn{2}{|c|}{ Fr. II } & \multicolumn{2}{|c|}{ PBS } \\
\hline & & \multicolumn{6}{|c|}{ Preincubation with } \\
\hline & & PBS & MLE & PBS & MLE & PBS & MLE \\
\hline \multirow[t]{5}{*}{ Expt. 1} & $1: 4$ & 70 & 71 & 69 & 90 & 86 & 94 \\
\hline & $1: 8$ & 62 & 74 & 59 & 91 & 78 & 92 \\
\hline & $1: 16$ & 45 & 71 & 48 & 99 & 66 & 94 \\
\hline & $1: 32$ & 40 & 70 & 47 & 101 & 66 & 100 \\
\hline & $1: 64$ & 17 & 81 & 26 & 101 & 56 & 95 \\
\hline \multirow[t]{4}{*}{ Expt. 2} & $1: 4$ & 73 & 72 & & & 100 & 94 \\
\hline & $1: 8$ & 102 & 97 & & & 102 & 100 \\
\hline & $1: 16$ & 96 & 98 & & & 101 & 100 \\
\hline & $1: 32$ & 84 & 100 & & & 82 & 99 \\
\hline
\end{tabular}

Conditioned Fluid was obtained by incubating cell monolayers pretreated with Fr. I,

Fr. II $(25 \mu \mathrm{g} / \mathrm{ml})$ and PBS in $0.2 \mathrm{ml}$ PBS per culture bottle.

Three-tenth $\mathrm{ml}$ of diluted conditioned fluid was mixed with an equal voloume of PBS or MLE, and incubated at $37^{\circ} \mathrm{C}$ for 30 minutes (Preincubation). Further incubation at $37^{\circ} \mathrm{C}$ (Expt. 1) or $25^{\circ} \mathrm{C}$ (Expt. 2) was done after adding $0.6 \mathrm{ml}$ virus diluted in PBS.

The numbers represent per cent infectivities of control. Infectivity of control, which contained PBS instead of the conditioned fluid and was kept in ice water, was $75.2 \mathrm{PFU} / 0.2 \mathrm{ml}$.

fluid from PBS-treated cells is as effective as MLE in protecting virus and the protection decreases by dilution unless MLE is added in the fluid. However, the conditioned fluid from Fr. I - or Fr. II - treated cells inhibit weakly but significantly virus infectivity. It is evident that this inhibitory effect is not due to the interference with virus adsorption to cell surface at the time of plaque assay since the pretreatment of cell monolayers with the conditioned fluid from Fr. I - or
Fr. II -treated cells does not affect the plaque formation as shown in Table 4. On the other hand, addition of MLE reverse the inhibition by the conditioned fluid from Fr. II but cannot reverse the inhibition by the conditioned fluid from Fr. I. These results leads to a speculation that the cells treated with Fr. I or Fr. II release some factor into fluid which inhibit virus infectivity.

Some component in MLE may probably combine with such an inhibitor released from Fr. II-treated cells making the 
TABLE 4

Effect of pretreatment of cell monolayers with "conditioned" fluid on plaquing effeciency

\begin{tabular}{c|c|c}
\hline $\begin{array}{l}\text { Pretreatment of cell } \\
\text { monolayers with con- } \\
\text { ditioned fluid from } \\
\text { cells treated with }\end{array}$ & Av. no. of Plaques & Plaquing efficiency \\
\hline Fr. I & 88.0 & 102 \\
Fr. II & 93.0 & 107 \\
PBS & 87.0 & 100 \\
Control $^{\text {a) }}$ & 86.5 & 100 \\
\hline
\end{tabular}

Conditioned fluid was obtained as described in Table 3 .

Cell monolayers were treated with $1: 2$ dilution of the conditioned fluid before adding the virus.

a) Cell monolayers pretreated with PBS.

inhibitor inactive, whereas, it does not affect the inhibitor from Fr. I -treated cells. Such an event accounts for the finding in preceding experiment (Table 2, Expt. 2) that, when virus in MLE was used for inoculation, practically the same recovery (total amount of adsorbed and unasorbed virus particles) was obtained in cell monolayers pretreated with Fr. II as in control monolayers, but only lower recovery in cell monolayers pretreated with Fr. I .

Effect of Fr. I and Fr II on virus clones. An experiment was carried out to confirm whether the reduction of plaques in pretreated monolayers was caused by some variants possibly contaminated in virus inoculum. Virus clones were isolated from the single plaques formed by adsorbed and unadsorbed virus to cell monolayers which were treated with PBS, Fr. I and Fr. II (Table 2, Expt. 2). Each clone was propagated passing once in cells, and tested on the plaque forming ability in treated or untreated cell monolayers. As shown in Table 5, the reduction of plaques formed in pretreated monolayers

TABLE 5

Effect of Fr. I and Fr. II on plaquing efficiency of virus clones derived from different origins

\begin{tabular}{|c|c|c|c|c|}
\hline \multirow[b]{2}{*}{ Clones derived from } & & \multirow{2}{*}{$\begin{array}{l}\text { no. of } \\
\text { clones }\end{array}$} & \multicolumn{2}{|c|}{$\begin{array}{l}\text { Plaquing efficiency in cell mono- } \\
\text { layers pretreated with } 20 \mu \mathrm{g} / \mathrm{ml} \text { of }\end{array}$} \\
\hline & & & Fr. I & Fr. II \\
\hline virus adsorbed to cells pretreated with & Fr. I & 4 & $19-28 \quad(23)$ & $57-73 \quad(62)$ \\
\hline " & Fr. II & 5 & $16-26 \quad(20)$ & $48-84 \quad(66)$ \\
\hline " & PBS & 5 & $20-27 \quad(24)$ & $47-75 \quad(68)$ \\
\hline \multirow{2}{*}{$\begin{array}{c}\text { virus unadsorbed to cells pretreated with } \\
\text { " }\end{array}$} & Fr. I & 8 & $12-28 \quad(19)$ & $40-73 \quad(55)$ \\
\hline & Fr. $\mathbb{I}$ & 8 & $17-25 \quad(20)$ & $43-81 \quad(61)$ \\
\hline " & PBS & 7 & $16-28 \quad$ (19) & $44-81 \quad$ （64） \\
\hline
\end{tabular}

Numbers in parenthesis represent the average values of plaquing efficiencies. 
were roughly comparable in clones regardless of their origins. It is, therefore, unlikely that the virus stock consisted of the mixed populations which contained variants with and without ability to attach to the pretreated cells.

Effect of heating on Fr. I and Fr. II. Fr. I and Fr. II $(1 \mathrm{mg} / \mathrm{ml})$ in PBS $(-)$ were heated at different temperatures and exposed to cell monolayers after being diluted 40 times with PBS (25 $\mu \mathrm{g} / \mathrm{ml}$ in final concentration). The plaque reducing capacity of Fr. I and II was maintained after heating at $56^{\circ} \mathrm{C}$ for 30 minutes. As shown in Fig. 5, Fr. II was very stable for heating at $100^{\circ} \mathrm{C}$. In contrast, Fr. I rapidly but partially lost the plaque reducing capacity at $100^{\circ} \mathrm{C}$, and maintained it thereafter at a constant level.

Digestion of Fr. I and Fr. II by trypsin. Two $\mathrm{ml}$ of PBS (-), Fr. I and Fr. II in PBS (-) were mixed with equal volume of $0.3 \%$ trypsin (DIFCO, $1: 250$ ) in $0.02 \mathrm{M}$ Tris (tris (hydroxymethyl) aminomethane) buffer, $\mathrm{pH}$ 8.0, and incubated at $37^{\circ} \mathrm{C}$. After digestion for two hours, the mixture was heated in boiling water for five minutes to inactivate the enzyme. The mixtures were diluted 7 times with PBS and used for estimation of plaque reduction.

Table 6 shows that the numbers of plaques formed in cell monolayers

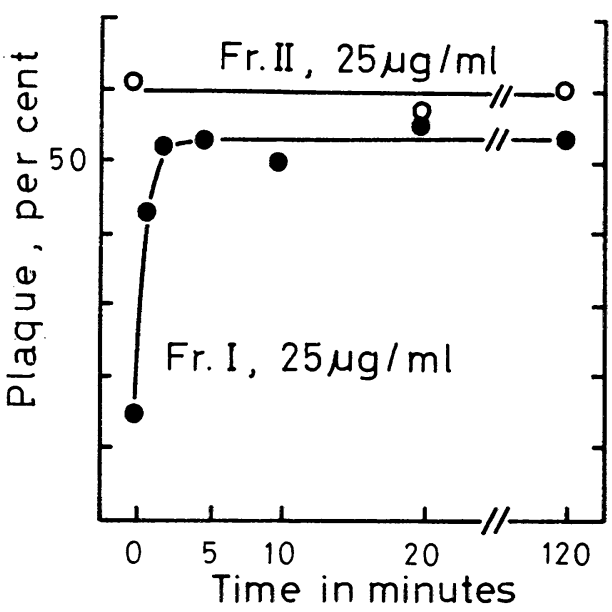

Fig. 5 Effect of heating on plaque reducing capacity of Fr. I and Fr. II.

Fr. I and Fr. II containing $1 \mathrm{mg}$ protein per $\mathrm{ml}$ in PBS (-) were heated in boiling water for indicated period. The cell monolayers were treated with heated sample after diluted 40 times with PBS.

treated with trypsin-digested Fr. I and Fr. II were as same as control. As Fr. I was partially heat labile (Fig. 5), another experiment in which the enzyme was inactivated by adding the bovine serum into reaction mixture after incubation was attempted and the same result was obtained. This clearly pointed out that the plaque reducing capacity was associated to the protein or protein moiety in substances contained in Fr. I and Fr. II.

TABLE 6

Effect of trypsin-digested Fr. I and Fr. II on plaqung efficiency

\begin{tabular}{|c|c|c|}
\hline Pretreatment of cultures with & Av. no. of plaques & Plaquing efficiency \\
\hline $\operatorname{PBS}(-)$ & 103.6 & 100 \\
\hline treated with trypsin & 115.0 & 100 \\
\hline Fr. I, $25 \mu \mathrm{g} / \mathrm{ml}$ & 15.6 & 15 \\
\hline treated with trypsin & 124.6 & 108 \\
\hline Fr. $\quad$ II, $150 \mu \mathrm{g} / \mathrm{ml}$ & 25.6 & 25 \\
\hline treated with trypsin & 117.2 & 102 \\
\hline
\end{tabular}


Amino acid composition of Fr. I and Fr. II. The qualitative amino acid analysis was carried out by twodimensional paper chromatography on acid hydrolysates of Fr. I and Fr. II. Fr. I and Fr. II were desalted by eluting with distilled water through Sephadex G-10 column and hydrolyzed by $6 \mathrm{~N} \mathrm{HCl}$ at $110^{\circ} \mathrm{C}$ for 16 hours in sealed ampules filled with nitrogen gas. The hydrolysates were condensed under reduced pressure and served for chromatography. Phenol-water containing $1 \%$ ammonia (4:1) and n-butanol-acetic acid-water (4:1:2) were used as developing solvents. Fourteen spots corresponding to amino acids and two unidentified spots were clearly separated on the chromatogram of hydrolysate of Fr. I. On the other hand, only seven spots were recognized in the hydrolysate of Fr. II. Those were isoleucine-phenylalanine, valine-methionine, alanine, glycine, serine, proline and arginine, among which the spot of arginine was especially large and intense in color. The relatively small amount of arginine was detected in Fr. I by visual comparison of spots on the chromatogram. This was also confirmed by Sakaguchi reaction ${ }^{7)}$ carried out on the paper. The result obtained on Fr. II was in accord with the amino acid analysis of salmine reported by Ando et $\mathrm{al}^{2)}$. It is, thus, confirmed that Fr. II contains only protamine molecules. The behavior in Sephadex column and the amino acid analysis clearly demonstrates that Fr. I does not contain the aggregates of protamine molecules but is composed of different protein( $(s)$ with higher molecular weight.

\section{DISCUSSION}

The commercial protamine sulfate could be separated into two fractions by Sephadex G-50 column which inhibited the virus-cell interation, one of which (Fr. I) contains high molecular weight protein(s) and the other (Fr. II) contains only protamine molecules.

Both fractions inhibit the plaque formation by herpes simplex virus in cell monolayers if the cells are treated with them before inoculation with the virus, although Fr. I inhibits much more efficiently than does Fr. II. As the plaque reducing capacity of $\mathrm{Fr}$. I is partially diminished by heating, it may be reasonable to consider that it contains several kinds of proteins.

Wallis and Melnick ${ }^{15)}$ found that protamine sulfate increased the number and the size of plaques formed by herpes simplex virus when it was introduced in agar overlay medium. Our previous study showed that it slightly increased the size of plaques but did not affect the number of plaques when it was introduced in agar ${ }^{16)}$. In the present experiment, it was confirmed that Fr. I and Fr. II did not affect or slightly enhanced virus replication when either of the fractions was added in the medium after virus adsorption (Fig. 4) and that they did not directly affect virus infectivity. On the other hand, if the cells are treated with the fractions before adding the virus, the number of plaques is reduced (Fig. 1). These findings lead to the assumption that the fractions neither inactivate the intra- and extracellular virus nor inhibit virus replication but they bind to the cell surface and in consequence prevent virus attachment to or inactivate virus on the cell surface. Binding of the substances to cells could be clearly demonstrated by removal of plaque reducing capacity of Fr. I and II by preincubation with cells (Table 1). The fact that the plaque reduction is due 
to the failure of virus attachment to pretreated cells became evident from experiments in which the number of PFU remaining in inoculum was determined after adsorption period (Table 2). This strongly supports the hypothesis proposed by Colter et al. ${ }^{3)}$ and by Craighead and Layne ${ }^{5)}$ that polycations block the receptor site by binding to the cell surface.

Craighead and Layne ${ }^{5)}$ failed to recover the unadsorbed virus from the inoculum which was applied to polycation-treated monolayers. In our experiment, such unadsorbed virus could be detected only when the virus diluted in MLE was used for inoculation but could not detected when the virus diluted in PBS was used. The data obtained here indicate that some factor will be released from cells pretreated with Fr. II which inactivate virus but could not inactivate it in MLE (Table 3). Although such a factor has not yet been characterized, it seems probably that it is the complex of protamine molecule and cell receptor, which, if it is once released into fluid will be capable of binding to virus particle and will result in inactivation of virus. Such a complex will be also capable of binding to some substances, probably protein or peptide, which are contained in skim milk or lactalbumin hydrolysate, and in consequence will diminish its capacity of binding to virus particle. In the case of $\mathrm{Fr}$. I, a similar complex will be released but not affected by MLE.

Protamine enhances adsorption of $\mathrm{P}^{32}$-labelled fowl plague virus to cells ${ }^{12}$ and DEAE dextran enhances infectivity of poliovirus and its infectious $\mathrm{RNA}^{12}$ ). The infectivity of rabies virus is remarkably enhanced by protamine or DEAE $\operatorname{dextran}^{9)}$ and that of respiratory syncytial virus is also enhanced by $\mathrm{DEAE}$ dextran and by low concentration of protamine ${ }^{11}$. On the other hand, protamine reduces infectivity of Semliki Forest virus but increases RNA infectivity ${ }^{4)}$. In addition, infection of mengo encephalomyelitis virus is inhibited by protamine ${ }^{3)}$. Our preliminary experiments showed that protamine enhanced markedly the plaque formation by measles virus and to a lesser extent by poliovirus, but reduced that by Sindbis virus. Such the contrasting effects of polycations among various viruses are probably due to the differences of surface structure of virus particles. Many authors have attributed the effects of polycations on virus infectivity to ionic charge. The experiment on a variant of encephalomyocarditis virus by Craighead and Layne supports this hypothesis ${ }^{5)}$. They observed that plaque formation by $\mathrm{r}^{+}$ variant was inhibited by basic polyamino acid to a greater degree at low than high $\mathrm{pH}$ values. However, our repeated experiments by using Fr. I and II and herpes simplex virus carried out by strictly the same manner did not give the results comparable to that obtained by them. It seems, therefore, unlikely to consider that the ionic charge is the sole factor in the effect of polycations on virus adsorption or infectivity.

Although no evidence was obtained that Fr. I and II affect the virus-cell interaction by the different mechanism, the data obtained here demonstrate that both fraction inhibit virus adsorption by binding to the cell surface. However, the biochemical mechanism by which the virus-cell interaction is inhibited still remains to be elucidated.

\section{LITERATURE CITED}

1) Allison, A. C. and Valentine, R. C. : Virus particle adsorption III. Adsorption of viruses by cell monolayers and effects of some variables on adsorption. 
Biochim. Biophys. Acta., 40, 400-410, 1960.

2) Ando, T., Ishil, S. and SAto, M.: Studies on protamines V. Amino acid composition of clupeine and salmine. J. Biochem., 46, 933-940, 1959.

3) Colter, J. S., Davies, M. A. and Campbell, J. B. : Studies of three variants of mengo encephalomyelitis virus. II . Inhibition of interaction with $\mathrm{L}$ cells by an agar inhibitor and by protamine. Virology, 24, 578-585, 1964.

4 ) Connolly, J. H. : Effect of histones and protamine on the infectivity of Semliki Forest virus and its ribonucleic acid. Nature, 212, 858, 1966.

5 ) Craighead, J. E. and Layne, C. H. : Contrasting effects of polycations on plaquing efficiency of encephalomyocarditis virus variants. J. Virol., 3, 45-51, 1969.

6) Dulbecco, R. and Vogt, M. : Plaque formation and isolation of pure lines with poliomyelitis viruses. J. Exptl. Med., 99, 167-182, 1954.

7) Greenstein, J. P. and Winitz, M. : Chemistry of the amino acids, vol.3, p. 1848. John Wiley and Sons, Inc., New York, 1961.

8 ) Kabuta, H.Yamamoto, S., Tanikawa, M. and NAKAGAWA, Y.: Thermoinactivation of $\mathrm{HF}^{2}$ and $\mathrm{M}$ strains of herpes simplex virus in various conditions. Kurume Medical J., 16, 91-99, 1969.

9 ) Kaplan, M. M., Wictor, T. J., Maes, R. F., CAmpbell, J. B. and Koprowski, H. : Effect of polyions on the infectivity of rabies virus in tissue culture : Construction of a single-cycle growth curve. J. Virol., 1, 145-151, 1967.

10) Lowry, O. H., Rosebrough, N. J., Farr, A. L. and RANDALL, R. J. : Protein measurement with the folin phenol reagent. J. Biol. Chem., 193, 265-275, 1951.

11) Nomura, S.: Interaction of respiratory syncytial virus with polyions: Enhancement of infectivity with diethylaminoethyl dextran. Proc. Soc. Exptl. Biol. Med., 128, 163-166, 1968.

12) Pagano, J. S. and VAheri, A. : Enhancement of infectivity of poliovirus RNA with diethylaminoethyl dextran (DEAE-D). Arch. Ges. Virus forsch., 17, 456-464, 1965.

13) Tilles, J. G. : Enhancement of interferon titers by poly-L-ornithine. Proc. Soc. Exptl. Biol. Med, 125, 996-999, 1967.

14) Vogt, P. K.: Enhancement of cellular transformation induced by avian sarcoma viruses. Virology, 33, 175-177, 1967.

15) Wallis, C. and Melnick, J. L. : Mechanism of enhancement of virus plaques by cationic polymers. J. Virol., 2, 267-274, 1968.

16) Yamamoto, S., Kabuta, H. and Nakagawa, Y. : Plaque formation by herpes simplex viruses in GMK (established grivet monkey kidney) cells. Kurume Medical J., 15, 221-234, 1968.

17) Yamamoto, S., Kabuta, H. and Nakagawa, $Y$. : Inhibition of herpes virus adsorption on cells by protamine. Kurume Medical J., 16, 83-89, 1969. 